\title{
ETNOGRAFIA DA LEITURA NUM GRUPO DE ESTUDOS ESṔIRITA
}

\author{
Bernardo Lewgoy \\ Universidade Federal do Rio Grande do Sul - Brasil
}

Resumo: O espiritismo kardecista é uma religião que confere fundamental importância ao estudo de uma literatura própria, entendida como complemento de uma revelação religiosa. Este artigo, realizado a partir de pesquisa etnográfica num tradicional centro espírita de classe média de Porto Alegre, examina e sistematiza alguns modos pelos quais os adeptos espíritas, estruturados em pequenos grupos, relacionam-se com essa tradição escrita.O grupo é fundamental na formação da identidade dos espíritas em dois aspectos: em primeiro lugar por demarcar pertencimentos internos, traduzidos ou não em diferenças de compreensão doutrinária. Em segundo lugar, é uma das instâncias de construção do expositor espírita, que ali aprende a tirar proveito de fórmulas verbais retiradas de um repertório próprio. Inspirado nas discussões sobre oralidade e escrita e na recente proposta de uma etnografia da leitura (Boyarin, 1993) tentarei mostrar que se a fala dos espíritas é construída como uma oralidade sustentada por textos, há também dimensões informais muito importantes a serem consideradas, que contextualizam e atualizam a relação com os textos sagrados nesse grupo.

Palavras-chave: cultura escrita, espiritismo, etnografia da leitura, oralidade.

\begin{abstract}
Kardecism is a religion which confers great deal of importance to the study of a specific literature, understood as the complement of a religious revelation. This article, based upon an ethnographic research in a traditional middle-class kardecist center in Porto Alegre, examines some ways through which the kardecists, structured in small groups, relate with this literate tradition. The group is fundamental in the spiritualist identity formation for two reasons: it limits the way people belong and identities, converted into differences of doctrine comprehension. Besides, it is one of the instances of construction of the spiritualist presenter, who learns to profit from the reading of texts aiming to place himself as an orator, helped by formulas extracted from a specific repertoire. Inspired by the discussions on orality and literacy and in the recent proposal of an ethonography of reading (Boyarin, 1993) I will try to show that, if the spiritualists' speech is built as orality supported by texts, there are also very
\end{abstract}

Horizontes Antropológicos, Porto Alegre, ano 10, n. 22, p. 255-282, jul./dez. 2004 
important informal dimensions to be considered which contextualize and update these group's relation with sacred texts.

Keywords: ethnography of reading, literacy, oral communication, spiritualism.

Religião de letrados, o espiritismo kardecista confere um status diferenciado - ao lado da caridade e de suas práticas rituais - à leitura e interpretação de uma bibliografia religiosa própria, que se inicia com a chamada Terceira Revelação ou Codificação de Allan Kardec, e que funciona como fonte de autoridade religiosa e constituição de identidades. ${ }^{1}$ Socializar-se no espiritismo significa familiarizar-se, estudar, falar bastante sobre os autores e obras canônicas, ou seja, ingressar num universo de debate e reflexão dominado por uma tradição religiosa escrita e letrada, permeado por uma "oralidade secundária" - no sentido de Ong (1982). A par dessa percepção da importância da cultura letrada no espiritismo, observei por um ano e meio um grupo de estudos num tradicional centro espírita, situado num bairro de classe média, próximo ao centro de Porto Alegre. O texto a seguir é uma etnografia da leitura entre espíritas, que segue a inspiração de Jonathan Boyarin (1993) e acompanha uma trajetória de discussão relacionada à "temática da oralidade e da escrita” (Goody, 1987, 1988; Havelock, 1996a, 1996b; Olson, 1997; Ong, 1982) no universo religioso.

\section{Indicacoões bibliográficas como ritos de autoridade}

Para as finalidades de nossa discussão, convém salientar que as indicações bibliográficas que os espíritas me faziam serviram não exatamente para estabelecer um recorte, mas para a própria introdução do pesquisador em campo. Ser iniciado é, em primeiro lugar, receber

\footnotetext{
${ }^{1} \mathrm{O}$ espiritismo kardecista delimita-se pela referência às obras de Kardec, basicamente $O$ Livro dos Espíritos, O Livro dos Médiuns, O Evangelho Segundo o Espiritismo, A Gênese e O Céu e o Inferno, apelidados de o "pentateuco kardequiano" (Kardec, 1982, 1984, 1991a, 1991b, 1997). A denominação “obras básicas” abrange os três primeiros títulos do conjunto, mas por serem consideradas pelos espíritas como formando a base essencial da Codificação, esta formada pelo conjunto da obra de Kardec. O Livro dos Espíritos é a referência básica de leitura para os grupos de estudos, em conjunto com cartilhas didáticas preparadas pela Federação Espírita Brasileira (FEB).
} 
orientações de leitura, como um principiante, qualquer que seja o pretexto para a aproximação. Há, no espiritismo, uma hierarquização estabelecida que presume não tanto a desigualdade de saberes, mas a desigualdade de esclarecimentos entre os espíritas e os não-espíritas. Quando fui comprar o Livro dos Espíritos pela primeira vez, no posto de venda de livros da Sociedade Espírita Allan Kardec (a mais antiga sociedade espírita de Porto Alegre, de 1894), um senhor advertiu-me que eu deveria comprar as três obras básicas se eu quisesse estudar Kardec, que não adiantava eu comprar só uma porque elas formavam uma unidade.

Essas orientações espontâneas são comuns nesse ambiente, encaradas como um dever daqueles que têm mais tempo de espiritismo. Se a idéia de uma "hierarquia de potencial" ${ }^{2}$ funcionava como um critério de diferenciação interna entre os espíritas, a "antigüidade na doutrina” também era usada pelos informantes como uma espécie de classificação hierárquica complementar, certamente importante num sistema religioso que tanto valoriza a igualdade entre os participantes. ${ }^{3}$ Por exemplo, ao questionar uma médium sobre a palestra doutrinária que esta havia proferido, foi-me respondido: "Ora quem sou eu para dar palestra, eu só comentei um trecho do Evangelho." Outra manifestação comum combinava modéstia e autoidentificação de antigüidade: "sem a pretensão de saber alguma coisa, é essa a minha convicção dentro dos meus modestos 28 anos de participação nas hostes do espiritismo".

A despretensão, combinada ao argumento de autoridade "28 oito anos de participação" compõem uma espécie de retórica da humildade, valor de múltiplas implicações na religiosidade espírita. Ela não apenas indica a presença de uma "atitude cristã”, associada à prática da caridade, como situa o médium numa posição de dependência e diminuição do eu que favorece a passagem do espírito comunicante.

Quando fazia observações na Livraria Espírita Luz e Caridade, a diretora da livraria manifestou o desejo de conhecer-me. Marcamos no centro espírita numa terça-feira à tarde, quando se realizaria uma palestra doutrinária com passes.

\footnotetext{
Essa idéia foi enunciada por Maria Laura Cavalcanti (1983).

${ }^{3}$ As hierarquias de posição na escala evolutiva nunca são objeto de discussão explícita entre os espíritas. Não há uma conversa ou estabelecimento de um ranking evolutivo. Os espíritas são treinados, no entanto, a identificar tendências ao conflito ou atitudes reprovadas como sinais de baixa evolução espiritual.
} 
O Instituto Espírita Luz e Caridade, com 65 anos de existência, é um dos centros espíritas mais conhecidos e prestigiados de Porto Alegre. Localizado num bairro de classe média da capital gaúcha, ele conta com dois prédios, divididos segundo a finalidade de uso: no primeiro funcionava o Departamento de Assistência Social, com creche para cerca de cem crianças, atividades de oficina (corte e costura e restauração de móveis) e organização de eventos beneficentes. Na entrada do terreno situava-se o prédio do Departamento Espiritual, onde se concentravam as atividades cotidianas dos freqüentadores da instituição: palestras, passes, atendimento fraterno, preces e irradiações (públicas), desobsessão, grupo de estudos e desenvolvimento mediúnico (privativas). O térreo contava ainda com uma pequena biblioteca e salas para as atividades de pequenos grupos, que ocorriam em datas e horários semanais fixos, respeitando a grande ênfase que os espíritas atribuem à pontualidade.

O centro, austero e despojado em seus tons de cinza e branco, era ornado com quadros de avisos, alguns cartazes, uma estante envidraçada com capas de edições antigas de livros de Allan Kardec, Gabriel Dellane, Camille Flamarion e Rochester - em tudo enfatizava a simplicidade do ambiente.

Após assistir à palestra e receber o passe, fui convidado para uma conversa, regada a chá e bolinhos. Estavam presentes no encontro os senhores Jader e Alberto, ambos diretores do centro, acompanhados de suas esposas, Andréa e Graça. Fui inquirido não apenas sobre meu trabalho, mas também sobre minha relação pessoal com o espiritismo, onde o mero "interesse científico" se afigurava pobre como justificativa. Nesses contatos iniciais eu registrava uma relação inversa à curiosidade de meus pares antropólogos sobre minha escolha de objeto, ainda que a grande questão fosse, para ambos, a de minha possível identidade espírita. Enquanto para os antropólogos assumir uma condição de espírita comprometeria o necessário distanciamento, para os espíritas isso era a condição para o bom entendimento da doutrina, pois “a razão não poderia deslanchar se não andasse de mãos dadas com a fé”.

Uma série de provocações foram lançadas durante a conversa, como uma espécie de teste de minhas posições, especialmente quando falavam de Chico Xavier e da impossibilidade de uma pessoa razoavelmente esclarecida não reconhecer a autenticidade de seu trabalho mediúnico. Não afrontando nenhuma das afirmações e sabendo de minha curiosidade em 
participar de um grupo de estudos e não meramente testemunhar sessões mediúnicas, meus interlocutores enquadraram-me na classificação de simpatizante da doutrina espírita. Como percebi, mais tarde, no grupo se delineava uma contínua expectativa de minha adesão à doutrina, categoria nativa que designa a conversão ao espiritismo e que remete à centralidade da noção de livre-arbítrio nesse sistema religioso, onde a própria aceitação da doutrina não pode prescindir do exame racional de seus postulados, ainda que uma situação de sofrimento ou perda possa ser considerada a motivação inicial para transpor a entrada de um centro espírita.

Fui conduzido à presença de Alberto, um homem de cerca de 50 anos, militar aposentado e dirigente do departamento espiritual do centro. Após o chá, ele perguntou-me sobre minha formação. Sem chance de lhe dar uma explicação maior sobre o teor do trabalho antropológico que desenvolvia, Alberto sentenciou: "O livro mais importante para você ler é $A$ Gênese, de Allan Kardec. Várias das coisas que poderiam te interessar estão aí.”

Parecia-me absolutamente inusitada a indicação, tão precisa a partir de tão poucos elementos. Mais tarde, vim a compreender que ele me tratou como alguém que ali fora em busca de uma orientação, dentro do continuum que vai do consolo à instrução. Eu, como antropólogo, não escapava à abrangência dessa certeza. Se o que me impelia a procurar o centro poderia ser o pretexto de uma pesquisa, descartada a alternativa de ser um adversário da doutrina, restava-me o lugar de um "espírita em potencial”. Dali para diante, eu iria aprender a doutrina espírita e teria o mesmo tratamento de todos os principiantes, devendo me submeter às normas de funcionamento do grupo. Meus informantes alternavam, assim, curiosidade com relação à pesquisa com uma ascendência de veteranos em face da minha posição de neófito, sempre na expectativa de uma adesão.

\section{Um grupo de estudos espírita}

Fui encaminhado ao grupo de Andréa, sua esposa, que se realizava às quintas-feiras, às 18h30. No dia em que lá cheguei, entrei numa sala onde vi cerca de dez pessoas à volta de uma mesa. Expliquei ao coordenador o que eu estava fazendo ali, ao que rapidamente ele me interrompeu afirmando que aquele não era o grupo de Andréa, mas eu poderia ficar ali, se quisesse. Meio constrangido aceitei o convite e, pelo que mais tarde eu entendi, aquela 
era uma decisão importante e eu não teria a liberdade de ficar alternando entre um grupo e outro grupo. Os grupos não se diferenciavam apenas pelo que eu supunha ser a diferença entre principiantes e adiantados, mas definiam pertencimentos e redes dentro do centro espírita, marcavam identidades, que se processavam principalmente pela filiação a um certo estilo de interpretação da doutrina espírita. O grupo de que participei ostentava um tipo de leitura mais "liberalizante", destacando o cunho social de algumas posições doutrinárias e, esporadicamente, opunha-se ao que consideravam o "conservadorismo" e "visão fechada" do "outro grupo".

Ainda que não houvesse homogeneidade de posições, a participação num determinado grupo de estudos tem uma nítida função identitária no universo espírita.

Certa vez Graça (a esposa do diretor do centro), que participava do “outro grupo", juntou-se a nós para a reunião de estudos. Conhecida por sua capacidade de polarizar e assumir posições bem marcadas, sua presença provocou uma viva reação de Ronaldo, o coordenador, que lhe indagou: "O que é que a senhora está fazendo aqui? O seu lugar é no outro grupo.” Mesmo após verbalizado este sentimento de invasão de fronteiras, Graça permaneceu na sessão e Ronaldo terminou por provocar um debate. Discutiu-se a maturidade do povo brasileiro para tomar suas decisões e a confiança que se deveria depositar nos seus governantes. Graça, então, posicionou-se afirmando que

quando o povo, tal como uma criança, não está maduro e tenta assim mesmo agir, a situação acaba numa bagunça, numa desordem; daí porque era necessário um governante com mão firme, como se fosse um pai severo, que tomasse para si a responsabilidade de tomar decisões para o bem daquele povo.

A fala logo foi identificada com a "simpatia pelo autoritarismo", e iniciou-se um debate acirrado, em que a própria existência de um carma coletivo chegou a ser invocada para interpretar a conjuntura brasileira. Sem deixar de reconhecer o interesse implícito do debate, importa ressaltar que, provocado pelo diretor do grupo, ele serviu para explicitar e marcar diferenças para os participantes, atualizando um jogo interno de identidades e pertencimentos dentro do centro. 
A relação com as fontes escritas era outro importante caminho de elaboração da identidade do grupo. A filiação a uma determinada exegese da doutrina espírita, em que a ênfase diferencial em determinadas referências, mais especificamente o que vale enquanto complementação às obras básicas, é tão importante quanto o estilo de interpretação realizado.

Tanto Ronaldo quanto seu amigo Aldair - químico, 28 anos de espiritismo - criticavam uma aceitação tida como "deslumbrada" de Emmanuel (o mentor espiritual de Chico Xavier) através de alusões ao que consideravam "frases estereotipadas", como "Emmanuel maravilhoso". Sem negar frontalmente a sua importância, os coordenadores insistiam que essa atitude de deslumbramento era contrária ao sentido do espiritismo, por obscurecer o exame racional das mensagens e induzir ao fanatismo. Os coordenadores alegavam que muita gente se escorava em clichês, sem conhecer direito nem a obra de Kardec, nem a de seus sucessores.

Como que chamando a um retorno às fontes originais da doutrina, Ronaldo afirmou ainda que: "o espiritismo, para nós, é a obra de Kardec mais as obras de Léon Denis e Gabriel Dellane”.

O que certamente seria diferente se o indicado como complementação a Kardec fosse Chico Xavier.

As sessões do grupo de estudos ocorriam semanalmente, com uma freqüência média de cerca de dez pessoas. Havia pessoas que se sentavam à volta da mesa e outras que preferiam permanecer numa posição mais periférica, numa segunda fileira de cadeiras. A proximidade dos participantes ao coordenador indicava, antes de tudo, uma disposição de intervir no debate.

Alguns liam os textos e outros ficavam com os olhos fechados, a testa franzida, a cabeça levemente arqueada para baixo e não eram perturbados pelos demais enquanto assim estivessem. $\mathrm{O}$ que me parecia uma preparação para o transe era um estado de concentração. Os espíritas acreditam que uma interrupção brusca de situações de concentração ou transe pode acarretar prejuízos físicos e emocionais ao médium. ${ }^{4}$ Como em outras

4 "Quando o médium está concentrado, exteriorizando fluidos naturalmente, qualquer choque que venha afetar o seu sistema nervoso não só o desconcentra como pode ser nocivo à sua saúde. Os que são despertados com violências poderão sofrer acidentes graves pelo choque vibratório e chegar mesmo a desencarnar, em virtude da inibição das forças magnéticas que mantêm o tônus vital orgânico. Quando isso não aconteça poderá sofrer, entretanto, queda de pressão sangüínea; outras desordens aparecerão, pondo o médium em desequilíbrio, ainda que seja por alguns dias.” (Toledo, 1993, p. 157).

Horizontes Antropológicos, Porto Alegre, ano 10, n. 22, p. 255-282, jul./dez. 2004 
situações, o médium que se concentra pode estar também objetivando a manutenção de vibrações positivas para o bom andamento da reunião. A prece, como já havia assinalado Cavalcanti (1983), é associada a uma interlocução com o alto: portanto, aquele que se encontra num estado visível, lido pelos demais como tal, é retirado do circuito de interlocutores ratificáveis, por se encontrar num "diálogo" de maior relevância.

Dentro do sistema de crenças espírita, toda atividade ritual demanda uma preparação do ambiente em que encarnados colaboram com desencarnados para uma faxina espiritual do ambiente, que acontece antes da sessão, equilibrando os fluidos presentes. Há sempre necessidade de um tempo entre as diversas atividades, a fim de que esse equilíbrio possa se restabelecer. Por exemplo, o grupo de estudos não funciona no mesmo dia da reunião de desobsessão, pois há o risco de que o ambiente não esteja ainda limpo das presenças espirituais que ocuparam o espaço, por isso a necessidade de um tempo razoável entre uma e outra atividade.

A atividade do grupo de estudos dividia-se em: 40 minutos de leitura e debate de uma passagem do Livro dos Espíritos e pouco mais de uma hora de leitura e debate de uma cartilha didática produzida pela Federação Espírita Brasileira (FEB). ${ }^{5}$ Com todas as atividades espíritas, a pontualidade era extremamente valorizada, ainda que nem sempre houvesse concordância quanto à sincronia dos relógios. A função do diretor do grupo não se esgotava no encaminhamento da atividade, estendendo-se a observações morais, por vezes de reprovação a atrasos, por vezes comentários sobre os participantes, onde uma a ironia podia se fazer presente. Com o tempo compreendi que a admoestação e a ironia compunham jogos de poder e autoridade que eram constantemente reiterados. Em certa ocasião Ronaldo advertiu Antônia pelo atraso de 15 minutos. Esta médium, muito respeitada no centro, retrucou: "no meu relógio não há atraso, o seu é que deve estar com algum problema”.

Como numa sala de aula os participantes do grupo eram levados a compreender que deviam uma espécie de satisfação por seus comportamentos.

\footnotetext{
${ }^{5} \mathrm{Na}$ cartilha didática, havia textos doutrinários, trechos de livros de Kardec, Emmanuel, André Luiz ou de algum intelectual espírita da FEB. Em cada unidade havia também questões e exercícios propostos, ao modo dos livros didáticos escolares.
} 
As jocosidades e os deboches, ainda que não predominassem, podiam escoar tensões e aludir a rivalidades e diferenças pessoais no interior do grupo. No espiritismo, ainda que se possam fazer comentários sobre atitudes que levem a crer no atraso espiritual de alguém, a regra é não fazer comentários sobre o estágio espiritual de evolução de alguém. O humor é, por vezes, o único caminho para realizar as avaliações mútuas e comparações interpessoais, como no seguinte exemplo: "O Zeca que é o mais evoluído de nós, não tem esse problema dos podres do passado."

Trata-se aqui de uma alusão irônica aos comentários que fluem no centro sobre o comportamento moral e espiritualidade desse médium. A ironia, ao explicitar comentários não-autorizados sobre a evolução espiritual de um colega, funciona como um recurso para inverter no sentido igualitário essa hierarquia presumida: "Isso de problema de casamentos provacionais, que a maioria das pessoas passa, não se aplica ao Clóvis e à Antônia, que são o casal vinte aqui do grupo.”

O humor dirigido a esse casal, muito valorizado pela percepção da qualidade de seu vínculo, cumpre a mesma função do exemplo anterior. No entanto, nem sempre a jocosidade é bem recebida. No segundo caso ela foi interpretada como sarcasmo, tendo sido rispidamente respondida por Antônia, dizendo "Não é verdade. Nós também temos os nossos problemas" sem a sinalização verbal do sorriso, quebrando assim o jogo de fala humorístico que havia se instaurado.

Num sistema de valores tão marcado por controles mútuos, por incentivos à extrema responsabilização da expressão e pelo decoro igualitário, é compreensível que, nos debates, seja estimulada a expressão bem marcada de posições por vezes fortes e explicitamente antagônicas, como tantas vezes testemunhei. Por menos importante que pareça, a expressão verbal é sempre carregada de sentido no espiritismo. Por conseqüência, enfatiza-se muito a responsabilidade individual com a linguagem, mas o decoro igualitário interdita a expressão pública de conflitos e diferenças pessoais que não trilhem o caminho da divergência fraterna de opiniões: a expressão verbal é idealmente marcada por um respeito absoluto ao outro e à sua individualidade. Cumpre assinalar também que, nas condições de um grupo que sobrepunha laços de amizade e conhecimento prévio, a sustentação permanente de um ethos de formalidade tornava-se extremamente penosa. Essas jocosidades aludiam eventualmente a 
diferenças de gênero, status matrimonial, profissão, faixa etária e à política. Expulsas pela porta estreita do igualitarismo kardecista, as diferenças reapareciam por meio de inserções jocosas durante os diálogos.

Não quero passar a impressão que estive alheio a essas tensões, que me remetem à citação que Bárbara Smith (2002) faz de Michael Thompson (1979) sobre os estilos culturais de lidar com monstros:

Por exemplo, algumas pessoas e comunidades parecem caracteristicamente fechar os seus portões para excluir monstros, outras tentam convertê-los, ainda outras estão preparadas para alargar ou rearranjar suas casas para reabsorvê-los e, claro, algumas pessoas e comunidades regularmente vão em frente e os matam. (Thompson apud Smith, 2002, p. 17).

Não sei se eu era considerado um tipo de monstro pelos informantes e se eles têm uma estratégia típica de lidar com monstros além do ritual de desobsessão, onde estes são racionalmente convencidos e docemente doutrinados a seguir os medianeiros espíritas cristãos. Também o monstro da ilegitimidade social e o sentimento de minoria acuada pela opinião dominante parecem estar há décadas afastados dos espíritas, mas a entrada de alguém como um antropólogo sempre pode reacender a memória coletiva da perseguição, ativando os mecanismos reativos da prova e da demonstração da verdade de seu sistema. ${ }^{6}$

\section{Leitura, diálogo e formação de orador espirita}

O esquema da sessão dividia-se em prece de abertura, leitura oral de trecho do capítulo, comentários do coordenador e debate, leitura e debate da cartilha didática e prece de encerramento, feita sempre por um membro do grupo a pedido do coordenador. Também as leituras orais são solicitadas pelo coordenador aos participantes, assim como comentários dos trechos lidos.

${ }^{6}$ Desenvolvi alhures (Lewgoy, 2000) a tese de que, condenando formalmente os dogmas e os rituais, o kardecismo ritualiza por outras vias, seja considerando a vida como uma prova, seja considerando o mundo como uma espécie de “escola”. Também no centro espírita não há diplomações, batismos de fogo ou provas explícitas para um principiante, a não ser quando assume tarefas específicas como trabalhador da casa, expositor ou médium. O que significa que as provas iniciáticas podem surgir a qualquer momento, de forma espontânea e incisiva.

Horizontes Antropológicos, Porto Alegre, ano 10, n. 22, p. 255-282, jul./dez. 2004 
O coordenador introduzia os debates e impedia a dispersão em conversas paralelas e corrigia o rumo da discussão quando julgava que havia um desvio do ponto central. Em vista do imperativo de formação do expositor espírita, enfatizava-se a ostentação de um modelo de expressão oral claro e de retórica didática, a ser seguido pelos demais. A fala de Ronaldo era gramaticalmente correta, sem gírias ou maneirismos de linguagem, em tudo enfatizando a presença de um modelo letrado e escolar em sua expressão.

O debate iniciava-se pela leitura oral do Livro dos Espíritos, sendo examinado e discutido parágrafo a parágrafo. Um colega lia a passagem selecionada e o coordenador inquiria se ele, ou outra pessoa desejava comentar o trecho. De qualquer forma, Ronaldo sempre retomava a palavra buscando a generalização, ainda que ela não necessariamente dissesse respeito à análise do trecho. Cada vez que se abrisse o debate, deveria se obter alguma conclusão, assimilada à noção de ensinamento. Por exemplo, discutiu-se um dia uma passagem do Livro dos Espíritos sobre a oposição dos cientistas ao espiritismo. O coordenador iniciou o debate afirmando que "há verdades relativas no texto, pois ele foi escrito há mais de cem anos e há coisas que mesmo os espíritos da época não tinham condições de entender".

Após um breve debate sobre as relações entre ciência e espiritismo, o coordenador pediu para lermos novamente uma frase sobre sociedades na espiritualidade superior:

No mundo dos espíritos também há uma sociedade boa e uma sociedade má; dignem-se, os que daquele modo se pronunciam, de estudar o que se passa entre os espíritos de escol e se convencerão de que a cidade celeste não contém apenas a escória popular.

Pela leitura que eu havia feito da Parte 11 da Introdução do Livro dos Espíritos, concluí que se tratava de uma resposta a determinadas objeções, como corolário de um argumento maior, o de que o espiritismo não pertence à ciência ordinária, mas estaria situado num patamar evolutivo superior. Para o grupo, outras implicações deveriam ser tiradas da discussão. Do que eu julgava ser um argumento de inspiração comteana, o coordenador inferiu platonicamente que 
Nosso mundo é uma cópia pobre do que ocorre na espiritualidade superior, tanto em suas faixas mais elevadas quanto nos setores mais baixos, que também são organizados. Ambos atuam sobre nós em equipes (gangues, fortalezas). Na espiritualidade inferior há equipes que se chamam a si próprias de justiceiros, eles atuam em todo o globo, especialmente sobre aquelas pessoas com quem eles supõem ter dívidas com eles, obsessionando-os. Há as equipes de espíritos evoluídos que controlam a liberdade dos menos evoluídos (atrasados), mas respeitam o seu livre-arbítrio, mesmo naqueles casos em que eles atuam por obsessão aos encarnados. Não há interferência direta até por que o crescimento geralmente se dá pela dor e pelo sofrimento, mas depois até agradecemos por isso.

Elvira, outra ativa participante do grupo, interveio dizendo que "a gente vem para ser testado. Tudo está programado pela evolução, para ver como tu agirás para evoluir."

Ao que o coordenador complementou:

É, a gente vem para ser testado - os obstáculos têm origem em nossas vidas passadas ou nessa vida. Depois dos 20 anos, já começamos a ter dívidas acumuladas desta vida. Depois dos 40 ou 50 anos, já começamos a resgatar dívidas acumuladas nesta vida.

Do alto de meu etnocentrismo cartesiano, o encadeamento da argumentação na Introdução do Livro dos Espíritos não se coadunava nem com o comentário isolado de cada parágrafo (ou de pequeno conjunto de parágrafos) nem com a forma como o grupo debatia o texto. Não que o debate estivesse desligado de uma ordenação referida ao texto: pressupunha-se uma continuidade metódica na leitura da obra de Kardec, bem como a incorporação progressiva das verdades contidas no texto. Assim, na semana seguinte, a leitura deveria iniciar exatamente do ponto onde se havia parado na semana anterior. Não se buscava uma incorporação linear de conteúdos, mas uma aplicação prática. A leitura no grupo servia de um pretexto para a discussão, que nunca deveria ser restrita ao texto: este abria o debate, mas não o circunscrevia.

O exercício do comentário visava extrair um ensinamento doutrinário em cada passagem lida. A regra implícita de exegese no grupo de estudos 
era sempre procurar totalizar, extrair um ensinamento, mesmo que a partir de fragmentos de textos. Numa visão de mundo que não admite a existência do acaso, não há fragmentos reais, eles sempre podem ser recuperados por uma teleologia implícita que cabe ao exegeta desvelar, mas essa exegese presume um método espiritual de abordagem do texto, antes que um conjunto lógico de instruções. Um texto perfeito remeteria à dificuldade de entendimento ao leitor, que não teria tido a capacidade, a humildade ou mesmo a determinação necessária para lograr êxito na interpretação. O máximo que se salientava era a inadequação tópica de uma ou outra afirmação. Como o coordenador enfatizava, "como o Livro dos Espíritos é a doutrina dos espíritos, mesmo a eles não foi permitido saber tudo e sim aquilo que, de acordo com a sua época e o seu grau de evolução eles poderiam entender".

A possibilidade de fazer correções no texto, ainda que abrisse uma janela para a crítica histórica da doutrina, não arranhava a crença na predominância de verdades doutrinárias essenciais. Não havendo uma dúvida metódica de fundo e presumindo-se que o essencial estava estabelecido, simplesmente não fazia sentido insistir numa atitude de dúvida sistemática perante o texto, típica dos céticos e materialistas. Ao seguir os gestos de leitura inaugurados pelo próprio Kardec, na exegese do texto bíblico, as possíveis contradições ou incompreensões eram ou recuperadas pela interpretação alegórica ou subsumidas pela ênfase no sentido espiritual, na totalidade ou no ensinamento principal presente nas linhas ou entrelinhas do texto. O ensinamento, ou sentido espiritual significa que o texto lido é uma ponte que não contém, mas permite o acesso ao conhecimento, se acompanhado da atitude espiritual adequada. ${ }^{7}$ Nos gestos de leitura dos membros do grupo não era apenas um processo intelectual que estava em curso, mas um crescimento em que o próprio espírito está implicado, seja pela assimilação de conteúdos, seja também pela circulação de vibrações no ambiente, seja ainda pela troca de experiências realizada no grupo.

Um efeito esperado dos ensinamentos adquiridos, como conhecimento com implicações morais e espirituais, era a regeneração ou

\footnotetext{
Olson (1997) sustenta que a leitura alegórica e espiritual da Bíblia - aquela que procura um sentido espiritual nas entrelinhas - predominou até a Reforma Protestante, quando surge o impulso que levou à crítica textual, especialmente ligada à separação do texto de suas interpretações.
}

Horizontes Antropológicos, Porto Alegre, ano 10, n. 22, p. 255-282, jul./dez. 2004 
reforma íntima do indivíduo. A mera erudição, isolada da moralização da conduta, era muito criticada no grupo, de onde se pode compreender as repetidas críticas feitas aos "cientistas" e aos "intelectuais”, reprovados por não associarem o seu conhecimento a uma moralidade cristã cuja expressão máxima é fornecida pela revelação espírita.

No grupo era atualizada simultaneamente uma visão moral de indivíduo, como agente moral livre e responsável por suas ações, e outra, associada, em que prevalece um discurso psicologizante sobre o "interno", sobre o indivíduo e suas emoções. A reforma íntima era uma importante vertente de elaboração do interno, como na prece, sendo recuperada na órbita de uma apreciação individualista, que a entronizava como condição de autenticidade das ações externas. Alguns sustentavam a posição do "tudo ou nada": ou a reforma íntima é integralmente levada a cabo ou infirmada pelos pequenos defeitos. Outros, mais liberais, encaravam-na como meta a ser progressivamente atingida apesar dos pequenos defeitos e retrocessos.

Os exemplos eram usados em dois sentidos fundamentais: um era o exemplo de caráter mais técnico, no qual se compartilhavam narrativas de intercâmbio mediúnico, suas dificuldades e soluções, e outro, de caráter moral, que relacionava a doutrina espírita a conjunturas políticas, a exemplos pessoais, a notícias e a fatos do cotidiano.

O comentário de caráter técnico era freqüentemente exemplificado por narrativas orais. Certa vez, comentando o trabalho de doutrinação, Ronaldo contou que:

Numa sessão de desdobramento, uma senhora entrou em contato com um faraó egípcio e seus discípulos, que estavam estacionados há milhares de anos sem evoluir, seguindo-se um trabalho de meses de esclarecimento.

Há nessas narrações o estabelecimento de um jogo especular em que o escrito remete à experiência e vice-versa, num trânsito circular incessante através do debate.

Um segundo recurso retórico freqüentemente utilizado era o da concordância com avanços da ciência, como na afirmação "a descoberta dos cromossomos já estava prevista nos romances de André Luiz".

Esta imagem de ciência poderia ser complementada por uma idealização rousseauniana da natureza, geralmente tida como perfeita em 
contraste com a "irracionalidade” e o "atraso" das condutas humanas. A notícia do índio queimado por jovens em Brasília provocou o seguinte comentário de Antônia:

Vejam, enquanto a macaca, que é irracional, salvou a criança humana, vejam o que esses meninos fizeram com o índio.Às vezes eu me pergunto se nós não somos as criaturas menos evoluídas deste planeta, que nós ainda teremos muitas encarnações para aprender a lição de Jesus "amai-vos uns aos outros”.

O comentário de notícias não apenas elaborava a exegese doutrinária do mundo à luz da doutrina espírita, como atualizava o espiritismo aos dilemas morais e conjunturas que marcavam os participantes.

O trabalho de interpretação de contextos extratextuais à luz da discussão oportunizada pelos textos sagrados tinha várias semelhanças com a escola religiosa judaica em Nova Iorque, discutida por Jonathan Boyarin (1993), apontando para uma característica comum a cursos e seminários de formação religiosa de leigos. Esse é o lugar de uma leitura comunitária e espiritual.

\section{lgualdade doutrinária e hierarquias informais}

As narrativas e exegeses efetuadas no grupo evidenciavam ainda o componente hierárquico do discurso dos espíritas, fundado na preeminência do espiritismo sobre as demais religiões e, por conseqüência, dos espíritas sobre as demais pessoas. Isso sempre era um tema polêmico no grupo. Alguns sustentavam que "dizer-se espírita nada garantia, assim como conhecer todos os preceitos evangélicos, se estes não fossem aplicados diariamente”. Como explicar a envergadura moral de muitos não-espíritas, de espíritos missionários, como Gandhi ou Madre Teresa de Calcutá, originários das fileiras de outras religiões ou mesmo de pessoas comuns, conhecidas dos membros do grupo, espiritualmente mais elevadas que muitos espíritas? Em alguns momentos levantava-se a questão:

- E se os nossos governantes fossem espíritas? Será que isso não levaria à solução de muitos problemas? 
Outro: - Mas declarar-se espírita não é garantia de nada. O sujeito pode ser de qualquer religião. Quantas barbaridades já se fizeram em nome da religião. Não é um governante, mas é dentro de todos nós que se deve promover a mudança.

Assim, a superioridade de esclarecimento de nada valeria, na visão de alguns membros do grupo, se não fosse associada uma responsabilização moral maior, com a exigência de um programa de reforma íntima. Ainda que a referência central fosse a doutrina espírita e os argumentos invocados devessem gravitar à volta desse referencial, os enunciados válidos e os argumentos brandidos davam um colorido fortemente pessoal à discussão. Não estava em questão apenas o aprendizado de um conjunto de conteúdos intelectuais, mas a capacidade de articular a doutrina com o vivido do fiel. Nesse sentido, a autoridade da fala decorria de fatores extradiscursivos como a credibilidade do falante como médium e trabalhador reconhecido, sua antigüidade no espiritismo - e discursivos, como a articulação dos enunciados, a clareza de sua exposição e a força racional de seus argumentos.

Um jovem casal, com pouco tempo de grupo tendia a monopolizar a palavra, polarizando em todos os debates. Alguns membros mais antigos do grupo se incomodavam com as falas freqüentes dos dois e uma pergunta que se ouvia era “quem é ele?” ou então “de papo ele é muito bom, quero ver na prática”, que poderia ser traduzida como "com que direito ele usa a palavra como um interlocutor ratificado dentro deste grupo?” Sendo o espiritismo um sistema formalmente igualitário, a estruturação hierárquica é implícita, o que se estende ao direito de uso e ao modo de expressão verbal, cabendo aos participantes ter o senso de seu lugar nos grupos de que participam. Ali conta mais a trajetória no espiritismo, as referências morais de cada um, do que o que era percebido como verbosidade vazia, através de uma linguagem hierárquica antiintelectualista que controlava moralmente os eventuais brilhos não-autorizados dentro do grupo.

Como nas demais situações no centro espírita, a hierarquia era presente de forma sutil, mas nunca explicitada, por contrariar a ideologia igualitária que permeia esse sistema religioso. Maria Laura Cavalcanti (1983), ao discutir as concepções nativas de indivíduo e pessoa, já havia chamado a atenção para a existência de uma hierarquia de potencial no espiritismo, ao que acrescentei acima a "antigüidade” como variável informal. Importante 
ainda é a coincidência entre hierarquia e responsabilidade no espiritismo: um respeito hierárquico devido a um médium corresponde a uma expectativa sobre o desempenho de sua função, assim como um maior controle moral sobre a sua vida pessoal.

Como anteriormente colocado, as posições hierárquicas no espiritismo sobrepõem a liderança carismática (implícita na hierarquia de potencial entre os médiuns) e a liderança burocrática (em que o que importa é a responsabilidade funcional do cargo), resultante da tensão entre a valorização diferencial dos médiuns e a ênfase igualitária da organização.

Estando a crítica racional prevista no espiritismo através da noção de "livre-arbítrio", é normal que os debates em torno da superioridade do sistema espírita sejam transpostos para uma hierarquização das diferenças intelectuais entre os homens como uma questão de aceitação da revelação espírita. Ora, como isso implicava numa óbvia dificuldade de assimilação da superioridade de um não-espírita em face de um espírita, esta era sempre passível de ser compensada, em outro plano, pela intransponível desigualdade de esclarecimentos, que reservaria um lugar exclusivo aos espíritas.

Isso converge com as observações de Laplantine e Aubrée (1990), para quem o espiritismo brasileiro é mais relacional e familiar do que o espiritismo europeu, mais centrado na comunicação, e com as conclusões de Sidnei Greenfield (1999), para quem esse familialismo repõe no plano religioso as tradicionais relações clientelísticas da sociedade brasileira. Como em outras instituições que emulam uma doutrina estatal na sociedade brasileira, como a burocracia do serviço público e o exército, uma ideologia marcadamente igualitária é muitas vezes relativizada por hierarquizações oriundas de uma dimensão particularista e personalizada, tão resistente quanto incapaz de justificar-se abstratamente.

\section{Preces e palestras: 0 orador espirita em accão}

Todos os trabalhos espíritas são abertos pela prece, concebida como uma relação direta de elevação e contato com a espiritualidade superior (Cavalcanti, 1983). Enfatizava-se o aprendizado de um timing, de um preciso comportamento lingüístico e de uma determinada atitude corporal. A técnica corporal era conhecida: as pessoas fechavam os olhos e se 
concentravam, com as mãos sobre a mesa ou em cima das pernas junto aos joelhos, manifestando respeito, humildade, subordinação e elevação. O timing era variável, mas não eram recomendadas preces longas no grupo, perfazendo no máximo um ou dois minutos. A prece era marcada por uma entonação de súplica, pausada, em voz alta e falada na primeira pessoa do plural, o chamado "plural majestático". Eram permitidas improvisações em torno de um molde formular, referido ao objetivo da reunião. Se o estudo estava em pauta, deveria haver frases que falassem disso na prece, ainda que sem um texto predeterminado.

Os termos adotados na prece eram retirados de um repertório de máximas e expressões que sinalizavam “o religioso” por uma analogia com um modelo erudito, onde abundavam expressões compósitas como "campo energético propício”, “mercadejávamos” ou "veneranda entidade”. Este uso religioso da linguagem está decalcado numa certa visão literária e retórica da expressão verbal, marcada por arcaísmos, predileção por categorias compostas (por vezes de três vocábulos) e o emprego recorrente de máximas morais durante os atos de fala. No caso da prece, há uma certa ordem hierárquica de mediadores que devia ser respeitada, de acordo com a importância atribuída a cada um:

Pedimos a Deus, nosso pai maior, a Jesus, a Allan Kardec e aos amigos espirituais que permitam o sucesso deste momento de meditação e aprendizado, permitindo que um campo espiritual positivo harmonize as nossas energias, sintonizadas no amor, na dedicação ao próximo e no desejo de aprender, e que somente espíritos de luz iluminem os nossos pensamentos neste trabalho tão importante que agora se inicia.

Em primeiro lugar, a prece era oral e coletiva, e podia ser complementada pela recitação grupal de uma prece decorada, como um painosso. Nesse sentido, ela seguia uma estrutura formular aberta, que viabiliza adaptações locais e individuais dentro de um esquema que todos conhecem e manejam. O espiritismo valoriza uma atitude tida e vista como interior, daí a liberdade estimulada de improvisar em torno do tema. A seqüência escalonada de referências era protocolar: não se admita uma elocução do tipo “agradecemos a Deus, aos amigos espirituais e a Jesus”, por 
desrespeitar a ordem hierárquica do maior ao menor.

A prece é um tema de ampla elaboração na literatura e na fala dos espíritas, guardando diferentes conotações além da referência comum de uma disposição espiritual de ligação e diálogo com um plano espiritual superior. Nesse sentido, ela é um importante pólo de reflexão sobre contatos espirituais, comportando diferentes usos e crenças subjacentes. Na prece, o fiel estabelece um contato com o alto, mas dentro da concepção espírita de pessoa (um compósito relacional de forças e entidades atraídas por afinidades e por carmas comuns) ela é concebida como irradiadora de uma espécie de força que atrai espíritos de diversos tipos. Isso tem por conseqüência a produção contínua de um imaginário espírita sobre a prece, que tematiza a sua função e aplicações nas mais variadas circunstâncias. Certa vez Ronaldo afirmou que em meditação havia concluído que sempre que se orar "deve[-se] fazer uma dupla oração, pelo irmão na mesma faixa vibratória, sendo também necessária uma terceira prece, pelos irmãos obsessores, encarnados ou desencarnados”.

O coordenador salientou também a importância de orar em voz alta, "senão os espíritos de baixa evolução, que necessitam de som, não escutariam”. Abriu-se, então, uma ampla discussão sobre as visões e as práticas de oração dos membros do grupo. Para alguns, a prece não era apenas uma invocação ou reza, mas um estado intuitivo a ser mantido 24 horas por dia. Para outros, isso era dependente do dia e do estado espiritual de cada um, de acordo com o clima que se percebe se faz um tipo de vibração e de prece. Elvira, a participante mais velha do grupo, cerca de 75 anos, relatou que costuma fazer preces pela manhã e à noite, antes de dormir. Certa vez ela achou que estava fazendo preces demais e diminuiu um pouco a quantidade de orações. Elvira relatou então que ficou doente por ter baixado a guarda ("com muitas dores no corpo, fechei os olhos e só via escuridão”) e os inimigos espirituais puderam agir. Teve que rezar muito, mas só conseguiu se desvencilhar da enfermidade com a ajuda de uma sobrinha, também médium, que lhe ajudou a fazer uma limpeza na casa.

Outros membros afirmavam que a prece nem necessita de palavras, é mais um estado, um pensamento amoroso que se difunde pelo fluido cósmico universal. Novamente aqui se expressa um conjunto aberto de crenças que caracterizaremos como complexo da prece. Em primeiro lugar, como o 
espiritismo coloca o pensamento numa posição englobante em relação à linguagem, é compreensível que a prece possa ter eficácia mesmo sem palavras, na forma de um estado.

A referência ao coração introduz um novo elemento no complexo da prece, ligado à concepção espírita de pessoa. O coração simboliza uma disposição ou atitude de fé genuína, que é condição de possibilidade da eficácia das preces. Ou seja, aponta para o uso de uma vontade individual livre não inteiramente identificada com a racionalidade, no sentido de um "fervor espiritual”. Os kardecistas acreditam que a fé deve compatibilizarse com a razão, mas agregam que "a fé sem razão leva ao fanatismo, e a razão sem fé levaria ao materialismo e ao ateísmo". Na tradição cristã ali cultivada, a dimensão do "coração" lembraria a atitude de simplicidade evangélica contra a hipocrisia, a sabedoria contra a ciência sem alma, sendo, portanto, uma instância permanente de endosso, junto com a esfera da caridade, da atitude crítica contra aqueles espíritas concentrados em pesquisas intelectuais.

Isto se coaduna, como já discutimos, com a separação espírita de linguagem, tida como um modo de comunicação dispensável para os espíritos, bastando-lhes o pensamento. A rede de oposições categoriais acionadas (que colocamos sob a rubrica da tensão emblemática espírito versus letra) é também derivada da oposição hierárquica pensamento versus linguagem - expressão da oposição maior espírito versus matéria - em que todo o veículo lingüístico, como uma muleta da ordem da matéria, é apenas um suporte instrumental para a comunicação do pensamento, estando em posição englobada e dependente da atuação deste, que lhe confere valor e sentido. ${ }^{8}$

A oposição entre prece improvisada versus prece decorada introduz a necessidade de um novo contexto formular. Não se decora uma prece, mas, do contrário, exercitam-se balizas verbais e retóricas, bem como a marcação do tempo e da modulação da voz do oficiante. O aprendiz deve

\footnotetext{
${ }^{8}$ A posição subordinada e instrumental do corpo e da linguagem em relação ao espírito e ao pensamento, no espiritismo, não significa desleixo com os veículos, mas todo um conjunto de preceitos e cuidados: no corpo as interdições de vícios e excessos, na fala um treinamento retórico constante. Retorna aqui a idéia de uma oposição hierárquica, e não equiestatutária entre matéria e espírito. Essa relação permite que se compreenda que, ainda que o mundo espiritual seja modelo e valor para o mundo visível, certas categorias de habitantes do mundo espiritual estão mais próximas da matéria que habitantes do mundo material - de onde uma oposição entre uma espiritualidade superior e uma espiritualidade “inferior”.
}

Horizontes Antropológicos, Porto Alegre, ano 10, n. 22, p. 255-282, jul./dez. 2004 
empregar injunções mnemotécnicas que levem em consideração o tom de voz e as recorrências rítmicas e semânticas que ele observa quando da realização da oração pelos veteranos. No grupo, a prece de encerramento era feita por qualquer um dos participantes, sempre a pedido do coordenador, sem um agendamento prévio, a fim de estimular essa construção formular de preces improvisadas. Os principiantes tendiam a fazer preces mais curtas, mas já mantinham a sua estrutura mínima: referência ao tema do estudo, seqüência hierárquica de agradecimentos do espírito de maior hierarquia ao de menor menor hierarquia, atualização do uso especial de linguagem através de vocábulos compostos incomuns na fala corrente, tom de voz modulado para a oração, emprego do plural majestático.

Ainda que a prece não necessite compulsoriamente de palavras, os espíritas consideram-se eticamente imbuídos de levar instrução e consolo aos irmãos encarnados e desencarnados mais próximos da matéria. Como os que estão nesse estágio de evolução ainda precisam de som, a forma lingüística, a reza em voz alta, também se faz necessária. Não há preces obrigatórias ou horários compulsórios para a sua realização, mas os livros espíritas citados pelos membros do grupo são unânimes em recomendar o despertar e o momento antes de dormir como o mínimo recomendado. A reza pela manhã suplica pela harmonia do dia, e a feita à noite - associada à leitura e meditação de trecho do Evangelho - relacionase à crença no descolamento do espírito do corpo durante o sono, sujeitando a pessoa a contatos espirituais inusitados e arriscados.

Havia, no grupo, diferenças de estilo e concepções de prece, com nuanças etárias e geracionais. Enquanto os membros mais velhos, como Elvira, tendiam a considerar a prece mais como uma prática codificada, com lugar e horário determinado, os membros mais jovens não operavam essa segmentação, tendo mais simpatia pela percepção da prece como um estado associado à intuição subjetiva do clima, categorizado pela oposição leve versus pesado. $\mathrm{Na}$ verdade, esses membros mais jovens conjugavam as duas visões, com uma clara preeminência atribuída à percepção da ubiqüidade da prece, englobando sem suprimir a concepção sustentada pelos mais antigos. Sua leitura enfatizava a vertente anti-ritualista do espiritismo, que inclusive sugeria a possibilidade de "ser espírita fora dos centros” e do próprio movimento espírita. Logo, o grupo registrava variações internas que não eram apenas suas, mas dos espíritas em geral, entre a inevitável codificação da prece em rituais públicos e práticas privadas, de um lado, e 
sua assimilação difusa a um estado constante e indiferenciado, de outro.

A discussão oral sobre a prece levantou um outro ponto, dificilmente sistematizado na literatura doutrinária. Trata-se de uma oposição entre uma dimensão ética e outra mágica nas práticas de oração. A dimensão ética corresponde a uma espécie de imperativo categórico da prática religiosa espírita: há um dever incondicional de dirigir-se e submeter-se ao plano espiritual superior, sem esperar privilégios ou calcular conseqüências. Na prece realiza-se uma concepção de diminuição da individualidade do médium como condição para a conexão reverente com as forças do alto. No entanto, as representações sobre a eficácia da prece apontam quase sempre para técnicas corporais: qual a atitude mental adequada, como a respiração deve ser conduzida, se há necessidade ou não da voz, etc. Esta fusão das dimensões expressivas e técnicas introduz a dimensão mágica na reflexão dos informantes, ainda que nem sempre explicitamente nomeada. Sendo o contato e a influência dos espíritos um dado permanente em sua visão de mundo e noção de pessoa, a prece necessariamente levará em conta a percepção de uma conjuntura relacional de contatos espirituais para o médium, mas os cursos de ação poderão dirigir-se ora a uma aceitação evangelizadora de todos esses contatos, ora ao emprego técnico ("mágico" num sentido etic) da oração para afastar essas influências. Nesse sentido, a narrativa de Elvira sobre a enfermidade causada pela diminuição do volume das preces é exemplar dessa dimensão mágica, bem como das ambigüidades da concepção de prece para os espíritas.

Por fim, o complexo da prece pode ser aproximado de uma lógica situacional que enfatiza aspectos diferenciados no molde abrangente e flexível de seu sistema de crenças, que faz com que ambas as dimensões, ética e mágica, possam estar presentes para a mesma pessoa, num mesmo momento. Isso permite que as preces sejam conduzidas em forma de diálogo, mais próxima da visão de autenticidade ou do coração, construção simbólica na qual ecoa a tensão teológica espírita entre pensamento (nível elevado, estado interior) e linguagem (nível baixo, formalização exterior).

Além da prece, a palestra doutrinária é um outro domínio de exercício de técnicas retóricas e corporais em que predominava a máxima, espécie de fórmula de múltiplo uso. Trata-se, no entanto, de uma estrutura formular diferente daquela empregada para a improvisação de preces. Enquanto esta se pautava pela improvisação em torno de um tema, seguindo uma determinada estrutura rítmica e semântica, aqui a fórmula torna-se máxima 
doutrinária. Não é simples descrever a força ilocucionária das máximas na retórica espírita. Elas são uma espécie de ensinamento condensado, que permite a fixação mnemotécnica da doutrina num corpus de frases curtas - por exemplo "viemos ao mundo para ser testados" ou "orai e vigiai", etc. - cumprindo um papel didático, como num sermão. Pode-se ter uma apreensão doutrinária em diversos níveis de aprofundamento, mas o conhecimento dessas máximas e suas explicações constituem o repertório mínimo que o espírita incorpora em sua trajetória religiosa. Além disso, a máxima funciona como um sinalizador verbal, que permite o trânsito de planos discursivos do particular para o geral e vice-versa, do texto ao comentário e deste ao exemplo, à narrativa. No grupo de estudos elas estão em muitas introduções de falas, como as que sublinhamos acima. Mas em palestras doutrinárias elas podem servir de operadores discursivos, preencher brancos na fala e também servir à guisa de conclusão. Toda a socialização no espiritismo é permeada pelo uso de máximas nas falas, como por exemplo

Viemos ao mundo para ser testados

O nosso mundo é uma cópia pobre do mundo espiritual

É pelo sofrimento que se chega à doutrina espírita.

O uso de máximas doutrinárias permitia que cada trecho lido em grupo pudesse ser associado a diversos tipos de atos discursivos, do comentário específico aos depoimentos pessoais, envolvendo intercâmbios mediúnicos, vidas passadas, méritos e faltas, exemplos de "espíritos missionários”, etc. Essas operações serviam para costurar os fragmentos discursivos em pequenas totalidades, que condensavam em clichês os princípios fundamentais da doutrina espírita.

A flexão das sentenças no chamado "plural majestático" - a primeira pessoa do plural - também era um dado lingüístico comum ao grupo de estudos e à palestra, juntamente com saudações fraternas, que constituíam as formas verbais próprias a essas situações, no interior de um modus operandi que tomava a expressão escrita como modelo para a fala. Seguindo esse esquema, o palestrante teria a capacidade de discorrer por horas a fio a partir de trechos de livros escolhidos ao acaso. Mas também poderia concluir a qualquer momento, o que nos introduz na segunda característica da inculcação de um habitus oratório no grupo de estudos: o 
enquadramento da fala ao tempo disponível, ou seja, a formação de um timing discursivo.

A adaptação da fala ao tempo disponível é uma habilidade das mais valorizadas no espiritismo kardecista. Se observarmos uma palestra doutrinária seguida de passe, veremos que os palestrantes sempre conseguem manter-se no tempo disponível, dificilmente passarão o limite de horário ou terminarão muito antes do previsto. A rígida observância de horários obriga os falantes a construir uma estratégia de adaptação ao tempo disponível que é aprendida nos grupos de estudo e tem por base os recursos retóricos aprendidos nos grupos de estudos. Uma palestra planejada lançará mão de um repertório de ensinamentos e máximas, onde o falante usa uma generalização, sinalizando um bloco da palestra, costurando-o à outra, e, ao aproximar-se do final da palestra, terminará recapitulando os pontos principais já enunciados no início da fala. Se é um comentário escolhido "ao acaso", 9 funcionará a fórmula do improviso, em que máximas e generalizações vão sendo continuamente costuradas e dissertadas no decorrer do tempo, alimentando um fluxo de discurso constituído não apenas da estrutura tradicional de um "começo-meio-e-fim", mas de vários pequenos "começos-meios-e-fins" em que as fórmulas verbais fazem o papel de partículas aditivas entre os segmentos da fala.

Ao aproximar-se do final do tempo, o expositor relacionará a última conclusão enunciada com o tema principal. Assim, é a estrutura formular oral da retórica espírita, tanto no plano das máximas quanto nas pequenas generalizações discursivas seqüencialmente encadeadas das palestras, que permite que um improviso - lido na ótica nativa através da categoria inspiração ${ }^{10}$ - obtenha êxito, mantendo-se sempre no tempo disponível.

A eficácia simbólica das palestras espíritas deve-se, em grande parte, à sua legibilidade descontínua, ou seja, à capacidade dos enunciados das máximas sempre se encaixarem no tema geral escolhido ao acaso, mas também às múltiplas chances de uma audiência heterogênea identificar-se e construir um sentido geral com pequenos segmentos da palestra, sem a necessidade de tê-la compreendida por inteiro. Pequenos discursos

9 Em verdade, “acaso” não é bem o termo correto. Geralmente o palestrante diz: “Aqui, no Evangelho, nos veio a seguinte passagem...”

10 Perguntando a palestrantes como procediam para fazer uma palestra com trechos escolhidos ao acaso, muitos me falavam que se sentiam transformados quando começavam a falar, explicando que isso só poderia ser uma inspiração do mundo espiritual.

Horizontes Antropológicos, Porto Alegre, ano 10, n. 22, p. 255-282, jul./dez. 2004 
descontínuos são costurados por um ritmo oratório e semântico contínuo, que permite que aparentes incoerências e ambigüidades no fluxo do discurso sejam percebidas pela audiência como dotadas de uma continuidade semântica maior. ${ }^{11}$

Isso não significa que todas as palestras reduzam-se a essa descrição, nem que isso forme um modelo exclusivo do espiritismo ou mesmo que possa ser generalizado a todo o universo dos que se reclamam espíritas. Talvez os momentos mais característicos de palestras com esse teor formular sejam os daquelas mais dirigidas a converter simpatizantes do que propriamente falar para adeptos, sobretudo quanto a fala do orador é acompanhada por um fundo musical.

\section{Conclusão}

A leitura em comum, seja em voz alta, seja silenciosa, era concebida como uma atividade de múltiplos fins, sempre sujeita à relação com outras inserções do fiel nos diversos espaços e atividades das casas espíritas. O fiel que estuda também dá passes, faz sessões de atendimento fraterno, desenvolvimento mediúnico, doutrina os espíritos na desobsessão, atividades que suscitam questões a serem discutidas no grupo de estudos, a instância interna de elaboração doutrinária mais reflexiva e dialogada do centro espírita. Englobada pelos imperativos de formação prática e ritual do espírita, é compreensível que a exegese no grupo de estudos seguisse uma coerência sutil entre fragmentos lidos em comum e um conjunto doutrinário pressuposto, de forma bem diferente da leitura do lector, valorizada nos quadros universitários (Bourdieu, 1991). Nunca mera aquisição de conhecimentos, o estudo não funciona bem, na visão espírita, se não estiver amparado por uma "inspiração espiritual”, uma conexão bem estabelecida e equilibrada com as forças espirituais supostas como presentes a qualquer situação humana. É essa “inspiração espiritual”, somada às relações formais e informais de autoridade entre os diversos participantes, que garante a coerência e a reprodução de um sentido ortodoxo a qualquer rumo que um debate possa tomar no grupo de estudos.

11 Estou aqui desenvolvendo uma idéia de Northrop Frye (1986), aplicada a um outro contexto: a cultura oral caracteriza-se pela conjunção entre a versificação contínua e a prosa descontínua, enquanto que a na cultura escrita verifica-se o inverso.

Horizontes Antropológicos, Porto Alegre, ano 10, n. 22, p. 255-282, jul./dez. 2004 
Isso nos remete à valorização simultânea da dependência e do livrearbítrio no espiritismo - para retomarmos os termos da discussão de Cavalcanti (1983) -, em que o intelecto recebe uma valorização ambígua e condicional. Sede simbólica do conhecimento e das decisões individuais, ela está englobada pelo imperativo maior de progresso moral, com a conseqüente introdução de um antiintelectualismo num sistema que tanto valoriza o estudo e o conhecimento.

A leitura e a conversa, no grupo de estudos, salientavam, além da reprodução da "leitura correta”, um disciplinamento pela forma que buscava a criação de uma competência retórica, de um habitus lingüístico de orador espírita. Nesse habitus, a conjugação verbal de um discurso descontínuo com um ritmo oratório contínuo, fundamental nas palestras de trechos lidos ao acaso, baseava-se na crença na subordinação do orador a um plano espiritual que inspira suas palavras, e que era indissociável do valor das diferentes práticas de leitura levadas a cabo no grupo de estudos. A leitura espírita remetia também à sedimentação doutrinária operada em sua literatura complementar, que realiza um incessante exercício de comentário e reiteração de seus textos sagrados. Além de remeterem uns aos outros, muitos textos de divulgação espíritas têm uma característica de redundância, funcionam sempre como chaves para a totalidade, resumem, sintetizam e recapitulam os pontos principais do sistema. Numa tradição iniciada pelo próprio Allan Kardec, eles podem ser lidos em diversos níveis de aprofundamento, com propósitos claramente didáticos, desde o manual de iniciação do leigo até o texto mais especializado e especulativo, destinado aos iniciados. A condensação, junto com a inserção do espiritismo na tradição cristã através das genealogias espirituais, fundamenta a sua eficácia simbólica através da uma elasticidade semântica de seu discurso, sempre adaptável às finalidades pragmáticas do auditório. Essa elasticidade semântica do discurso espírita permite, desde a retomada da inspiração bíblica do Novo Testamento, onde os espíritas podem resumir todo o sentido de sua doutrina na citação "ama a teu próximo como a ti mesmo", até discursos altamente especializados, destinados a um público restrito.

A fala e o estudo no grupo de estudos eram essencialmente uma fala e um estudo de convertidos, simultaneamente "ontológica” e “dialógica”, para adaptarmos a distinção que Jonathan Boyarin (1993) faz entre o Novo e o Antigo Testamento. Estudava-se e discutia-se não para aceitar ou refutar a doutrina, mas para poder prosseguir o trabalho de iniciação pessoal, 
participação nas atividades de trabalho do centro espírita e realizar proselitismo.

\section{Referências}

BOURDIEU, Pierre. O campo intelectual: um mundo à parte. In: BOURDIEU, Pierre. Coisas ditas. São Paulo: Brasiliense, 1991. p. 169180.

BOYARIN. Jonathan (Org.). The ethnography of reading. Berkeley: University of California Press, 1993.

CAVALCANTI, Maria Laura. O mundo invisível: cosmologia, sistema ritual e noção de pessoa no espiritismo. Rio de Janeiro: Zahar, 1983.

FRYE, Northrop. El camino crítico: ensayo sobre el contexto social de la crítica literaria. Madrid: Taurus, 1986.

GOODY, Jack. A lógica da escrita e a organização da sociedade. Lisboa: Edições 70, 1987.

GOODY, Jack. Domesticação do pensamento selvagem. Lisboa: Editorial Presença, 1988.

GREENFIELD, Sidnei. Cirurgias do além: perspectivas antropológicas sobre curas espirituais. Petrópolis: Vozes, 1999.

HAVELOCK, Eric. A musa aprende a escrever. Lisboa: Gradiva, 1996a. HAVELOCK, Eric. A revolução da escrita na Grécia e suas conseqüências culturais. Rio de Janeiro: Paz e Terra, 1996b.

KARDEC, Allan. A gênese: os milagres e as predições segundo o espiritismo. Rio de Janeiro: Federação Espírita Brasileira, 1982.

KARDEC, Allan. O céu e o inferno ou a justiça divina segundo o espiritismo. Brasília: Federação Espírita Brasileira, 1984.

KARDEC, Allan. O livro dos espíritos. Brasília: Federação Espírita Brasileira, 1991a.

KARDEC, Allan. O livro dos médiuns. Brasília: Federação Espírita Brasileira, 1991b.

KARDEC, Allan. O Evangelho segundo o espiritismo. São Paulo: Petit, 1997.

LAPLANTINE, François; AUBRÉE, Marion. La table, livre et les esprits: naissance, évolution et atualité du mouvement social spirite entre France et Brésil. Paris: J. C. Lattès, 1990. 
LEWGOY, Bernardo. Os espíritas e as letras: um estudo antropológico sobre cultura escrita e oralidade no espiritismo kardecista. Tese. (Doutorado em Antropologia Social)-FFLCH, Universidade de São Paulo, São Paulo, 2000. $360 \mathrm{f}$.

OLSON, David. O mundo no papel: implicações conceituais e cognitivas da leitura e da escrita. São Paulo: Ática, 1997.

ONG, Walter. Orality and literacy: the technologizing of the word. New York: Methuen \& Co., 1982.

SMITH, Barbara Herrnstein. Crença e resistência: a dinâmica da controvérsia intelectual contemporânea. São Paulo: Unesp, 2002.

THOMPSON, Michael. The creation and destruction of value. Oxford: Oxford University Press, 1979.

TOLEDO, Wenefredo. Passes e curas espirituais. São Paulo: Pensamento, 1993.

Recebido em 10/05/2004

Aprovado em 01/06/2004 